Nursing News: Jurnal Ilmiah Keperawatan Vol 5, No Tahun 2021, hal 16-23

Tersedia online di https://publikasi.unitri.ac.id/index.php/fikes

ISSN 2527-9823(online)

\title{
Reaksi Psikologis Anak Belajar Daring (Online) Pada Masa Pandemi Covid-19 Di Sdn Sumberejo 1 Purwosari Pasuruan
}

\author{
Wahidyanti Rahayu Hastutiningtyas ${ }^{1}$, Yanti Rosdiana ${ }^{2}$ \\ Universitas Tribhuwana Tunggadewi \\ e-mail :_abc_1yanti@yahoo.com
}

\begin{abstract}
Covid 19 upsets all communities, especially elementary school students. The impact of the covid 19 pandemic can occur directly or indirectly, for example there will be unstable emotions, excessive stress, anxiety, trauma and other symptoms. The effect will have an impact on a person or community. Learning in schools that switch to online learning can also have an impact on the psychological aspect of the child. This study aims to find out the Psychological Reactions of Children Learning Online at SDN Sumberejo 1 Purwosari Pasuruan. This type of research is descriptive analytics. The research respondents were students at SDN Sumberejo 1 Purwosari Pasuruan, sampled 47 respondents with total sampling techniques. The data was collected using the Strengths and Difficulties Questionnaire (SDQ). Results are univariately analyzed and presented in a frequency distribution manner. The result is that almost all students of SDN 1 Sumberejo 1 purwosari pasuruan bave normal strengths and difficulties in 3 indicators, namely behavioral problems, peer problems and prosocial abilities. Cooperation between parents and teachers needs to be improved so that children's psychological reactions can be normal as when studying at SDN Sumberejo 1 Purwosari Pasuruan.
\end{abstract}

Keywords : Psychological Reactions; Online Learning; Covid-19 Pandemic

\begin{abstract}
ABSTRAK
Covid 19 membuat resah semua kalangan masyarakat, khususnya pada siswa sekolah dasar. Dampak pandemi covid 19 dapat terjadi secara langsung maupun tidak langsung, misalnya akan terjadi emosi yang tidak stabil, stres yang berlebihan, cemas, trauma dan gejala lainnya. Efek yang terjadi akan berdampak pada seseorang atau kelompok masyarakat. Belajar di disekolah yang beralih dengan pembelajaran secara daring (online), juga dapat memberikan dampak pada aspek psikologis anak. Penelitian ini bertujuan mengetahui Reaksi Psikologis Anak Belajar Daring (Online) di SDN Sumberejo 1 Purwosari Pasuruan. Jenis penelitian ini adalah deskriptif analitik. Responden penelitian adalah siswa di SDN Sumberejo 1 Purwosari Pasuruan, didapatkan sampel sebanyak 47 responden dengan teknik pengambilan total sampling. Data dikumpulkan dengan menggunakan kuesioner Strengths and Difficulties Questionnaire (SDQ). Hasil yang dianalisis

Cara mengutip: Hastutiningtyas, WR., Rosdiana,Y.( 2021). Reaksi Psikologis Anak Belajar Daring (Online) Pada Masa Pandemi Covid-19 Di Sdn Sumberejo 1 Purwosari Pasuruan.. Nursing News: Jurnal Ilmiah Keperawatan. Vol 5, No 21, 2021, hal 16-23 Retrieved from https://publikasi.unitri.ac.id/index.php/fikes/article/view/2256
\end{abstract}



secara univariat dan dipaparkan secara distribusi frekuensi. Hasilnya adalah hampir semua siswa SDN 1 Sumberejo 1 purwosari pasuruan memiliki kekuatan dan kesulitan yang normal di 3 indikator yaitu masalah tingkah laku, masalah teman sebaya dan kemampuan prososial. Kerjasama antara orang tua dan guru perlu ditingkatkan lagi agar reaksi psikologis anak dapat normal seperti saat belajar di SDN Sumberejo 1 Purwosari Pasuruan.

Kata kunci : Reaksi Psikologis; Belajar Daring; Pandemi Covid-19

\section{PENDAHULUAN}

Tahun 2019 telah terjadi wabah pandemik yang disebabkan oleh coronavirus diasese 2019 atau disebut dengan Covid-19. Wabah pandemik ini mulainya di Kota Wuhan yaitu tepatnya di Tiongkok dan menyebar dengan cepat didunia dan salah satunya adalah Indonesia (Benerjee, 2020). Pada tanggal 2 Maret 2020, Indonesia sudah terpapar covid-19, kasus terus naik dan meluas di seluruh daerah di Indonesia. Kasus kematian di Indonesia semakin meningkat. Tanggal 9 Juli 2020, Kementrian Kesehatan melaporkan 70.736 kasus Covid-19 dengan 3.417 kasus meninggal (CFR 4,8\%) (Kementrian Kesehatan Republik Indonesia, 2020).

Kejadian pandemi ini sangat berdampak pada semuanya. Covid-19 sudah menginfeksi ratusan jiwa seluruh dunia dan ribuan jiwa masyarakat yang ada di Indonesia. Tindakan yang dilakukan pemerintah Indonesia adalah dengan mengeluarkan Surat Edaran Nomor 4
Tahun 2020 tentang Pelaksanaan Kebijakan Pendidikan Masa Darurat Penyebaran Coronavirus Disease (Covid19) adalah kesehatan dan keselamatan peserta didik, pendidik tenaga pendidikan keluarga dan masyarakat merupakan prioritas utama dalam menetapkan kebijakan pembelajaran. Pihak Sekolah Dasar mulai mengubah strateginya yaitu semua siswa belajar dari rumah (Kementrian Kesehatan Republik Indonesia, 2020).

Belajar di rumah artinya dimana semua anak-anak yang tadinya belajar disekolah beralih dengan pembelajaran secara daring (online), dalam proses pembelajaran daring (online) ini memberikan dampak pada beberapa aspek dimana salah satunya berdampak pada aspek psikologis anak sekolah (Cintiasih, 2020). Dampak psikologis anak terjadi karena beberapa keluhan yang dirasakan pada saat pembelajaran daring (Online) diantaranya yaitu 
minimnya sinyal, terbatasnya paket data, kesulitan dalam tugas kelompok, keefektifan belajar berkurang, banyaknya tugas, selain itu anak-anak mengalami perubahan reaksi terhadap keseharian dan lingkungan (Mahmudah, 2020). Dampak perubahan reaksi anak akan tampak lebih berbeda, dimana satu anak dengan yang lainnya mengalami perubahan reaksi yang tidak sama, hal ini dikarenakan anak yang sulit untuk mengungkapkan apa yang dirasakan atau yang dipikirkannya dan terkadang anak tersebut belum paham apa yang terjadi (Keliat \& Martiana, 2018).

Meutia (2020) mengungkapkan bahwa pandemik covid 19 ini tidak hanya berpengaruh pada banyak orang tapi juga pada kondisi psikologis anak. Sebagian besar anak mungkin dapat tangguh dan tidak stress ataupun trauma, akan tetapi ada beberapa anak yang mengalami beberapa efek kesehatan mental yang permanen. Hal ini bisa disebabkan karena tidak memiliki cukup makanan, tempat tinggal yang stabil, menjadi sangat sakit sendiri atau mengalami kerugian pada masa pandemik covid-19 ini.

Komisi Perlindungan Anak Indonesia (KPAI) mendapatkan 51 kasus dimana dengan adanya belajar daring (online) anak menjadi cepat lelah dan capek karena kegiatan pembelajaran yang dilakukan secra online. Apabila anak menjadi terbebani, maka bisa menimbulkan reaksi anak pada kesehatan psikis yang justru akan mempengaruhi imunitas pada anak. Widiyono, dkk (2020) mengatakan dampak psikologis reaksi anak dalam proses pembelajaran daring adalah cemas. Cemas dapat mengakibatkan masalah stress yang akan dapat menganggu aktifitas sehari-hari pada anak tersebut.

Proses pembelajaran yang dilakukan di rumah secara online akan berdampak siswa mudah mengalami stres. Pembelajaran yang diberikan seharusnya dapat mengarahkan siswa untuk tetap dapat menggali kemampuan yang dimilikinya serta tetap mengarah pada kompetensi yang seharusnya dicapai oleh siswa (Salahudin, 2010). Proses pembelajaran yang baik dapat dilihat pada kondisi siswa yang secara psikis baik serta suasana hati siswa yang stabil tetapi bila terjadi keadaan yang sebaliknya maka siswa akan mengamuk dan tidak dapat dikendalikan, misalnya muncul perasaan penakut, pemarah, mudah stres, cepat putus asa sehingga tidak akan tercapai proses pembelajaran yang diinginkan dan 
prestasi siswa akan turun (Rahmi, 2013, Yandri et al, 2020)

Pembelajaran daring (online) sudah dilakukan di SDN Sumberejo 1 Purwosari Pasuruan dengan melalui bimbingan orang tua di rumah. Berdasarkan hasil studi pendahuluan pada 5 siswa yang menjalani proses beajar (online) selama masa pandemi didapatkan bahwa siswa merasa binggung kenapa diliburkan sekolah lama, merasa bersedih karena tidak bisa bertemu dengan teman-temanya lagi disekolah dan gelisah karena biasanya belajar langsung bertemu dengan guru di sekolah sekarang melalui daring (online). Berdasarkan pernyataan tersebut, maka perlu dilakukan penelitian yang bertujuan mengetahui reaksi psikologis anak belajar daring (online) pada masa pandemi covid-19 di SDN Sumberejo 1 Purwosari Pasuruan.

\section{METODE PENELITIAN}

Penelitian yang dilakukan menggunakan deskriptif analitik dengan teknik total sampling dengan jumlah populasi sebanyak 47 responden dan jumlah sampel 47 responden. Penelitian dilaksanakan pada Juni 2020 pada siswa yang menjalani proses belajar (online) pada masa pandemi. Penelitian diberikan pada siswa kelas 4 dan 5 di SDN Sumberejo 1
Purwosari Pasuruan.

Data dikumpulkan menggunakan kuesioner yaitu dengan kuesioner Strengths and Difficulties Questionnaire (SDQ), yang terdiri dari 25 pertanyaan. SDQ terdiri dari 5 indikator yaitu emosi, masalah tingkah laku, inaterasi-hiperaktivitas, masalah teman sebaya dan kemampuan prososial. Data hasil penelitian dianalisis dengan univariat yang dipaparkan secara distribusi frekuensi.

\section{HASIL}

Tabel 1 menunjukkan mean usia responden 9,21 tahun. Tabel 2 menunjukkan terbanyak responden berjenis kelamin perempuan dan terbanyak kelas 4. Tabel 3. Menunjukkan bahwa aspek emosi hampir setengah normal, masalah tingkah laku hampir seluruhnya normal, aspek Inaterasihiperaktifitas hampir setengah normal, Masalah teman sebaya hampir seluruhnya normal, dan Kemampuan Prososial hampir seluruhnya normal 

Tabel 1. Usia Responden ( $\mathrm{n}=47$ )

\begin{tabular}{cccc}
\hline Mean & SD & Min & $\max$ \\
\hline 9,21 & 0,414 & 9 & 10 \\
\hline
\end{tabular}

(Analisa Data Tahun 2020)

Tabel 2. Karekteristik Responden $(\mathrm{n}=47)$

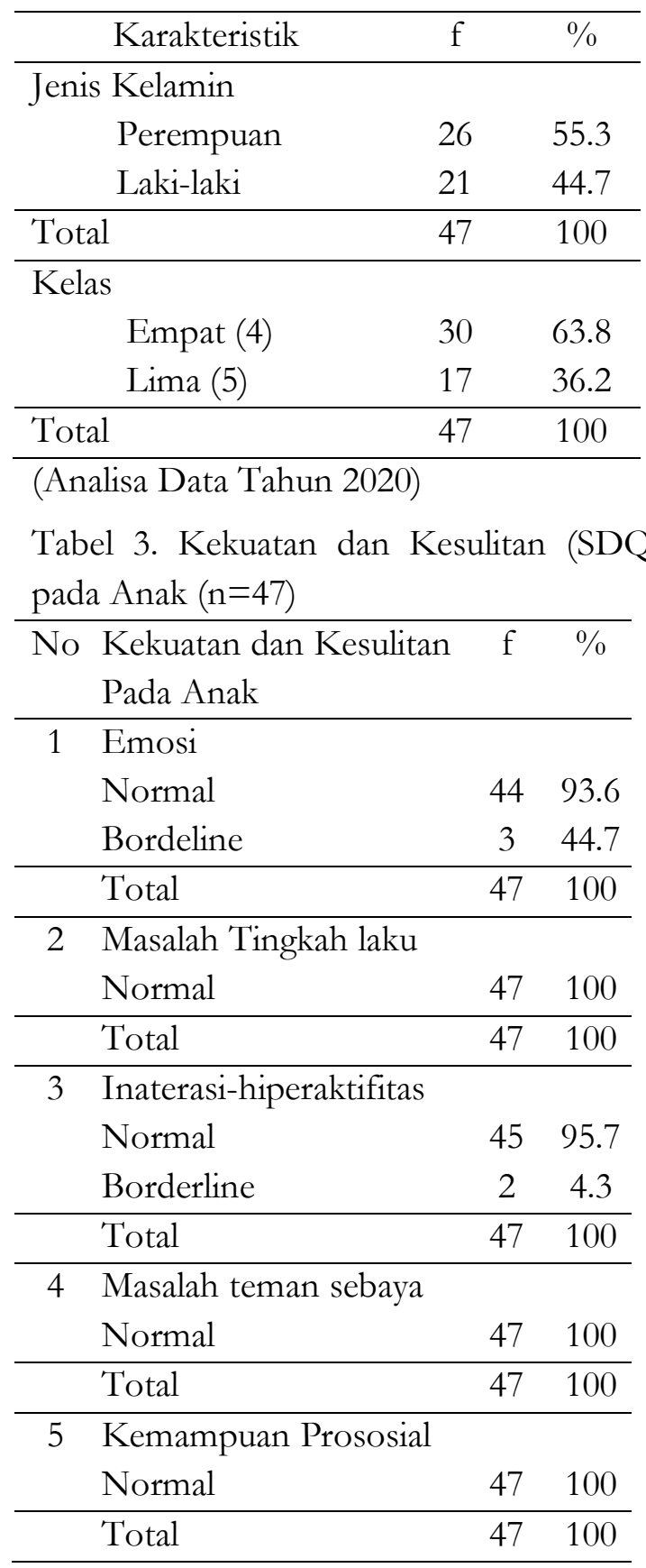

(Analisa Data Tahun 2020)

\section{PEMBAHASAN}

Berdasarkan hasil penelitian didapatkan hampir semua siswa SDN 1 Sumberejo 1 Purwosari Pasuruan memiliki kekuatan dan kesulitan yang normal pada tiga indikator yaitu $100 \%$ yang terdiri dari indikator masalah tingkah laku, masalah teman sebaya dan kemampuan prososial. Hal ini bisa disebabkan karena adanya dukungan keluarga yang baik pada saat pembelajaran daring (online) di rumah, sehingga para siswa dapat beradaptasi dengan baik dengan lingkungan disekitarnya. Keluarga merupakan kesatuan yang terkecil dalam masyarakat, peran keluarga sangat penting dan vital yang berpengaruh pada kehidupan anak termasuk reaksi psikologis anak pada saat pembelajaran daring (online) (Yunianti \& Nurtanti, 2015).

Selain dukungan keluarga hal lain yang menyebabkan tiga indikator normal dalam penelitian ini adalah mekanisme koping anak, koping artinya sebagai apa yang dilakukan oleh seseorang untuk menguasai suatu situasi yang dinilai mengancam. Pada saat anak-anak harus belajar daring (online) di rumah, anak akan cenderung bosan dan jenuh sehingga akan membuat reaksi psikologis anak yang kurang baik, untuk mengatas 

i hal tersebut orang tua perlu memberikan aktifitas seperti mewarnai, sehingga membuat anak dapat meningkatkan mekanisme koping adaptif (Astarani \& Sukoati, 2012).

Faktor lain dalam kesiapan anak belajar adalah kematangan/pertumbuhan pada anak, cerdas, banyak latihan, punya motivasi, dan ada faktor pribadi. Faktor sosial dari keluarga dan guru dengan cara mengajarnya, perlengkapan belajar seperti alat tulis dan buku yang digunakan untuk belajar, lingkungan yang mendukung anak belajar dan kesempatan anak untuk belajar, serta motivasi yang didapatkan dari lingkungannya/sosial (Purwanto, 2013).

Berdasarkan hasil penelitian juga didapatkan terdapat dua indikator yang hasilnya borderline yaitu emosi sebesar $44.7 \%$ dan interasi-hiperasktifitas sebesar 4.3\%. Hal ini bisa disebabkan karena kelakatan, kelekatan merupakan kedekatan seorang anak yang dapat mempengaruhi emosi dah interaksihiperaktifitas, dimana anak lebih dekat dengan guru disekolahnya saat belajar dan pada saat pembelajaran daring (online) di rumah membuat perubahan reaksi psikologis pada anak tersebut (Wibowo dkk, 2019). Penelitian Namu (2015) mengungkapkan bahwa seorang anak yang memiliki kelekatan akan belajar dari hubungan subyek lekatnya, anak tersebut akan memiliki rasa aman sehingga membuat anak mampu mengatur emosi dan hubungan interaksinya.

Faktor lain yang mempengaruhi dua indikator hasilnya borderline adalah trauma anak, dimana peristiwa-peristiwa sebelumnya yang sangat berkesan atau sangat mengecewakan anak akan berdampak pada emosi dan interaksi anak, bisa saja saat anak belajar daring (online) dirumah merasa sendiri dan itu sangat berbeda dengan disekolah yang biasanya belajar bersama di sekolah. Riggs (2010), mengungkapkan bahwa pola asuh merupakan salah satu yang membuat anak trauma, misalnya pengasuhan yang sering mengabaikan pengalaman emosi anak, dingin dan tidak konsisten.

Hal lain yang sering terjadi pada anak yang menjalankan proses belajar disekolah adalah harus mengikuti semua proses belajar dari awal sampai akhir di sekolah. Kondisi yang terjadi pada masa pandemi anak harus menjalani dengan perasaan sering cemas, takut, dan tugas yang diberikan lebih banyak dari sebelumnya sehingga beban anak 

bertambah. Sistem pembelajaran yang baru dan anak harus belajar menggunakan smarphone, komputer/laptop dan jaringan internet harus ada untuk melengkapi sistem belajar secara daring (online).

Kondisi ini membuat siswa harus beradaptasi dan biasanya akan merasa tidak betah untuk belajar di rumah sehingga anak merasa cemas dan stres. Stres yang ditimbulkan seperti tugasnya banyak yang harus diselesaikan, lama belajar akan bertambah, dan sering mendapatkan nilai ulangan yang jelek (Nurmaliah, 2014). Padahal, dalam proses belajar hendaknya anak merasa nyaman dan senang agar tujuan pembelajaran tercapai. Kondisi yang diinginkan akan merubah tingkah laku, sikap, kebiasaan, ilmu pengetahuan, dan keterampilan. (Dalyono, 2009).

\section{KESIMPULAN}

Hasil penelitian disimpulkan bahwa hampir seluruh siswa SDN 1 Sumberejo 1 purwosari pasuruan memiliki kekuatan dan kesulitan yang normal pada 3 indikator yaitu masalah tingkah laku, masalah teman sebaya dan kemampuan prososial. Terdapat 2 indikator yang hasilnya borderline yaitu emosi dan interaksi-hiperaktifitas. Dengan demikian tidak smua anak memiliki respon psikologis yang sama pada saat pembelajaran daring (online) pada masa pandemik ini, Kerjasama antara orang tua dan guru yang baik sangat dibutuhkan agar reaksi psikologis anak dapat normal seperti saat belajar disekolah.

\section{UCAPAN TERIMAKASIH}

Terimakasih kepada kepala sekolah SDN Sumberejo 1 Purwosari Pasuruan yang telah memberikan waktu untuk peneliti melakukan penelitian dan dapat mengumpulkan data serta kepada siswa di SDN Sumberejo 1 Purwosari Pasuruan yang telah bersedia menjadi responden penelitian.

\section{REFERENSI}

Banerjee, D. (2020). The COVID-19 outbreak: Crucial role the psychiatrists can play. Asian journal of psychiatry, 50,

102014.DOI: 10.1016/i.aip.2020.102 014

Cintiasih, T. (2020). Implementasi Model Pembelajaran Daring Pada Masa Pandemi Covid-19 Di Kelas Iii Sd Ptq Annida Kota Salatiga Tahun Pelajaran 2020.

Dalyono, M. (2009). Psikologi Pendidikan, 5 th Edition, Jakarta: Rineka Cipta

Keliat, B. A. (2018). Dukungan kesehatan jiwa dan psikososial (mental health 

and psychosocial support): keperawatan jiwa

Mahmudah, S. R. (2020). Pengaruh Pembelajaran Daring terhadap Psikologis Siswa Terdampak Social Distancing Akibat Covid 19. AlMau'iz̧boh, 2(2).

Meutia, A. (2020). Dampak Pandemi Covid 19 Pada Psikis Dan Ingatan Anak. Elementary School Journal Pgsd Fip Unimed, 10(1), 60-66. DOI: https://doi.org/10.24114/esip gsd.v10i1.19287

Nanu, D. E. (2015). The Attachment Relationship with Emotional Intelligence and Well-Being. Journal of Experiential Psychotherapy/Revista de PSIHOterapie Experientiala, 18(2).

Nurtanti, S., \& Ratnasari, N. Y. (2015). Dukungan Keluarga Terhadap Perkembangan Psikologis: Konsep Diri Pada Anak Usia Sekolah Dasar Di Desa Lebak Kecamatan Pracimantoro. Jurnal KEPERAWATAN GSH, 4(2).

Nurmaliah, F. (2014). Menurunkan Stres Akademik dengan Menggunakan Teknik Self Intruction, Jurnal Pendidikan Humaniora, 2 (3). DOI: $10.26539 /$ pcr.22321

PPKPA, P. P., \& Terlampir, Y. D. P. S. (2013). Kementerian Kesehatan Republik Indonesia. Profil kesehatan Indonesia tabun.

Pramudyani, A. V. R., \& Asmorojati, A. W. (2020). Pelatihan peningkatan kesadaran hukum terhadap kekerasan seksual pada anak usia dini berdasarkan UU Perlindungan Anak. In Seminar Nasional Hasil Pengabdian Kepada Masyarakat (pp. 755-764).

Rahmi, N. (2013). Hubungan Tingkat Stres dengan Prestasi Belajar Mahasiswa. Jurnal Stikes U'budiyah, 1(2).

Riggs, S. A. (2010). Childhood emotional abuse and the attachment system across the life cycle: What theory and research tell us. Journal of Aggression, Maltreatment \& Trauma, 19(1), 5-51. https://doi.org/10.1080/109267709 $\underline{03475968}$

Salahudin, A. (2010). Bimbingan dan Konseling, 2 th Edition. Bandung: Pustaka Setia.

Sukoati, S., Astarani, K., \& Kediri, S. R. B. (2012). Aktivitas Bermain Mewarnai Dapat Meningkatkan Mekanisme Koping Adaptif saat Menghadapi Stres Hospitalisasi pada Anak. Jurnal Stikes, 5(2).

Widiyono, A. (2020). Efektifitas perkuliahan daring (online) pada mahasiswa pgsd di saat pandemi covid 19. Jurnal Pendidikan, 8(2), 169177.

Wibhowo, C., Andromeda DS, K., \& Santoso, J. G. (2019). Trauma Masa Anak, Hubungan Romantis, dan Kepribadian Psikologi, 46(1), 63-71 